\title{
HRVATSKA AKADEMIJA ZNANOSTI I UMJETNOSTI I HISTORIOGRAFIJA O HRVATSKOM SREDNJOVJEKOVLJU
}

\begin{abstract}
O ulozi i važnosti Hrvatske akademije znanosti i umjetnosti u razvoju historiografije koja proučava srednjovjekovno razdoblje hrvatske povijesti najiscrpnije govore podaci, okupljeni u obljetničkim pregledima ili spomenicama o radu Akademije, napose u posljednjoj, kojom je godine 2011. obilježeno stoljeće i po od njezina utemeljenja, ali sustavna procjena te uloge još uvijek nije napisana. ${ }^{1} \mathrm{U}$ malobrojnim cjelovitim pregledima o razvoju hrvatske historiografije Akademija se spominje više-manje usput, s težištem na podacima o njezinoj izdavačkoj djelatnosti, pa je u tim tekstovima uloga Akademijina izdavaštva uglavnom primjereno istaknuta, ali je važnost Akademije u razvoju hrvatske historiografije samo iznimno vrednovana.

Ključne riječi: historiografija o srednjovjekovlju; Hrvatska akademija znanosti i umjetnosti; hrvatska povijest; bibliografija.
\end{abstract}

Tako se, naprimjer, Ferdo Šišić u historiografskom uvodu u svoju fundamentalnu knjigu Povijest Hrvata u vrijeme narodnih vladara (1925.), u pregledu o počecima moderne hrvatske historiografije u sredini 19. stoljeća, ograničava na točan zaključak da „rad oko hrvatske historiografije steče još krepču bazu osnutkom Jugoslavenske akademije znanosti i umjetnosti, naročito otkad je ona započela sistematskim djelovanjem svojim (1867.), i to ne samo objelodanjivanjem historijske građe, nego i izdavanjem historijskih monografija (rasprava) u svom organu Radu“, ali se u njegovu kasnijem razlaganju uloga Akademije samo neizravno prati, prije svega ocrtavanjem djelovanja njezinih istaknutih članova, povjesničara, kakvima su bili Franjo Rački, Tadija Smičiklas i Vjekoslav Klaić. ${ }^{2}$

150 HAZU 1861 - 2011, ur. F. ŠANJEK, Zagreb 2011, 53-55, 58-72.

2 F. ŠIŠIĆ, Povijest Hrvata u vrijeme narodnih vladara, Zagreb 1925, 34. O trojici istaknutih hrvatskih povjesničara druge polovice 19. i početka 20. st. usp.: M. GROSS, Vijek i djelovanje Franje Račkoga, Zagreb 2004; Zbornik Odsjeka za povijesne znanosti Zavoda za povijesne i društvene znanosti Hrvatske akademije znanosti i umjetnosti, vol. 18, posvećen 150. obljetnici rođenja Tadije Smičiklasa, Zagreb 2000; Vjekoslav Klaić, život i djelo, Zbornik radova, Zagreb - Slavonski Brod, 2000. 
Nove preglede o razvoju hrvatske historiografije objavio je godine 1960. i 1980. u dva enciklopedijska članka Jaroslav Šidak. U prvome je djelovanje Akademije na razvoj hrvatske historiografije prije svega iskazano podacima o njezinu izdavaštvu, pa se, primjerice, ističe da je između 1904. i 1916. „izašlo 13 svezaka Smičiklasova Diplomatičkog zbornika", i da su do godine 1918. objavljena 43 sveska u seriji Monumenta spectantia historiam Slavorum meridionalium. Između dvaju svjetskih ratova Akademija se, nastavlja autor, „u svojoj izdavačkoj djelatnosti uglavnom ograničila na objavljivanje znanstvenih radova", a nakon obnove djelatnosti 1947. godine ona je pokrenula neke nove serije, primjerice Građu za gospodarsku povijest Hrvatske, u kojima su iskazana nova metodološka nastojanja za pomnijim istraživanjima ekonomskog i društvenog razvoja. ${ }^{3}$

Nasuprot tome, $\mathrm{u}$ drugom, znatno iscrpnijem i koncepcijski temeljitijem, članku o razvoju hrvatske historiografije iz godine 1980., Jaroslav Šidak primjerenu pozornost obratio je i na djelovanje Akademije. U odjeljku o hrvatskoj historiografiji između 1850. i 1918. godine autor govori o prvom naraštaju moderne hrvatske historiografije, koji je bio okupljen oko Ivana Kukuljevića i njegova Arkiva za povjestnicu jugoslavensku, i ističe da je već „Kukuljević započeo sa široko zasnovanim izdavanjem izvorne građe“, ali da je "tek Akademija mogla za sustavni rad te vrste osigurati potrebna novčana sredstva“. Šidak upozorava da je Akademija 1904. godine „pristupila izdavanju Diplomatičkog zbornika u redakciji Tade Smičiklasa“ i da su „1908. počeli izlaziti i monumentalni Prinosi za hrvatski pravno- povjestni rječnik Vladimira Mažuranića“. Ocrtavajući razvoj hrvatske historiografije između 1918. i 1945., isti autor zaključuje da je „Akademija i dalje ostala jedina ustanova koja je mogla provoditi jedan sustavno zamišljen izdavački plan i uz to organizirati rad na skupljanju izvorne građe", ali ističe da je u tom razdoblju „i ona bila primorana da na duže vrijeme sasvim obustavi izdavanje nekih svojih serija namijenjenih upravo objavljivanju izvorne građe". U odjeljcima, pak, o razvoju hrvatske historiografije između 1945. i 1980., autor upozorava na reorganizaciju Akademije koja je „dovela do ubrzanog otvaranja različitih instituta“, među kojima spominje Historijski institut u Zagrebu, utemeljen 1948., Historijski institut u Dubrovniku, utemeljen 1949., i Institut Jugoslavenske akademije u Zadru, utemeljen 1954. godine. ${ }^{4}$

Jaroslav Šidak je, prema tome, u ovom drugom članku upozorio na neke ključne značajke $u$ djelovanju Akademije i njezinu utjecaju na razvoj hrvatske historiografije od utemeljenja Akademije do 1980. godine, ali smatram da smo

J. ŠIDAK, Historiografija, Hrvatska, Enciklopedija Jugoslavije, sv. 4, Zagreb 1960, 11-12.

4 ISTI, Historiografija, Enciklopedija hrvatske povijesti i kulture, ur. I. KARAMAN, Zagreb 1980, 203$205,207,210$. 
danas, nakon više od stoljeće i po njezina djelovanja, ipak dužni ulogu Akademije u razvoju historiografije o hrvatskom srednjovjekovlju još pomnije razmotriti. Pri tome će temeljnom tezom biti zaključak da je Akademija u cjelokupnom svojemu djelovanju bila osnovica na koju se oslanjala hrvatska medievalna historiografija, odnosno da bi bez te Akademijine osnovice razvoj historiografije bio znatno sporiji i teži jer u nekim ključnim segmentima, napose u sustavnom izdavanju široke lepeze povijesnih vrela, Akademiju nijedna druga hrvatska institucija, ma koliko bila zaslužna za historiografiju, primjerice Zemaljski arkiv, danas Hrvatski državni arhiv u Zagrebu, nije mogla u potpunosti zamijeniti.

Preglednosti radi, izlaganje će u ovom prilogu biti podijeljeno u tri glavna razdoblja: prvo, od utemeljenja Akademije do kraja Prvoga svjetskog rata 1918. godine, drugo, od 1918. do kraja Drugoga svjetskog rata 1945. godine, i treće, od obnove Akademije 1947. godine do danas.

\section{Od utemeljenja Akademije do kraja Prvoga svjetskog rata}

U prvom razdoblju djelovanja Akademije njezine su temeljne zadaće na području historiografije bile: prvo, izdavanje povijesnih vrela i drugo, objavljivanje fundamentalnih znanstvenih studija, $\mathrm{u}$ kojima se prije svega iskazivao napredak hrvatske historiografije, napose u njezinu Radu, kako je to već 1925. godine istaknuo Ferdo Šišić.

No da bi se izbjegli bilo kakvi nesporazumi u ocjeni o ulozi Akademije u razvoju historiografije o hrvatskom srednjovjekovlju, valja istaknuti, kako je dobro poznato, da su se izvori za hrvatsku povijest proučavali i objavljivali i znatno prije utemeljenja Akademije, već od hrvatske barokne historiografije. $\mathrm{O}$ tome svjedoče djela Ivana Luciusa Lučića De regno Dalmatiae et Croatiae libri sex, objavljeno u Amsterdamu godine 1666. i Memorie istoriche di Tragurio ora detto Traù, tiskano u Veneciji 1673. ili, pak, velebno djelo Danielea Farlatija Illyricum sacrum, objavljeno između 1751. i 1819. godine. A kada je u sredini 19. stoljeća nastajala moderna hrvatska historiografija, Ivan Kukuljević godine 1850. utemeljuje Društvo za jugoslavensku povjestnicu i starine, a 1851. godine počinje izdavati Arkiv za povjestnicu jugoslavensku, u kojemu je objavljivao i izvornu građu. ${ }^{5}$ I Društvo i Arkiv, dakle, prethode utemeljenju Jugoslavenske akademije znanosti i umjetnosti,

\footnotetext{
T. SMIČIKLAS, Život i djela Ivana Kukuljevića Sakcinskog, Rad 110, 1892, 110-204. Kukuljević, naprimjer, već 1859. počinje objavljivati izvode iz Dnevnika (I Diarii) Marina Sanuda pod naslovom: Odnošaji skupnovlade mletačke prema Južnim Slavenom priobćeni u izvadcih. Iz rukopisnih ljetopisah Marina Sanuda, Arkiv za povjestnicu jugoslavensku, sv. V, 1859, 1-160; VI, 1863, 161-476; VIII, 1865, 1-256, XII, 1875 , 257- 336, s građom do godine 1528. Nastavak građe iz Dnevnika Marina Sanuda objavio je F. RAČKI, Izvodi za jugoslavensku poviest iz dnevnika Marina ml. Sanuda za g. 1526-1533, Starine, knjiga XV, 1883, 177-240; XVI, 1884, 130-208; XXI, 1889, 133-183; XXIV, 1891, 161-203; XXV, 1892, 103-133.
} 
ali je ipak, kako je već istaknuo Jaroslav Šidak, tek Akademija mogla započeti sa sustavnim i promišljenim objavljivanjem vrelâ za hrvatsku povijest, što je bio jedan od temeljnih preduvjeta za razvoj moderne hrvatske historiografije. Zbog toga na samom početku valja postaviti ključno pitanje: što je omogućilo takvu ulogu Akademije, ili drugim riječima, tko su bili nositelji takve zadaće?

Nositeljima bijahu trojica pripadnikâ prvog naraštaja moderne hrvatske historiografije, Šime Ljubić, Matija Mesić i Franjo Rački, dok je četvrti od njih, među njima najstariji, Ivan Kukuljević, imao vlastita uporišta u Društvu i Arkivu, koji je izlazio do 1875. godine, pa je uglavnom ostao izvan djelovanja Akademije. No i spomenuta trojica počinju svoju istraživačku djelatnost prije utemeljenja Akademije, točnije, prije nego što je car i kralj Franjo Josip I. u ožujku 1866. potvrdio njezina Pravila, a Akademija započela svoju stvarnu djelatnost. Šime Ljubić već je znatno ranije započeo svoja široko razvijena istraživanja na različitim područjima, pa 1867. godine, dakle u vremenu kad je Akademija tek počela djelovati, u Rijeci objavljuje Pregled hrvatske poviesti. ${ }^{6}$ Jednako tako i Matija Mesić svoj prvi rad, Hrvati na izmaku XV. i na početku XVI. vieka, tiska 1864. i 1865. u zagrebačkom Knjižeoniku.

Prilike su se temeljito promijenile u času kad su obojica postala "pravim“, dakle redovitim članovima Akademije - Šime Ljubić 1866., a Matija Mesić 1867. godine. Ljubić već 1868. počinje objavljivati u prvoj knjizi novoutemeljene Akademijine serije Monumenta spectantia historiam Slavorum meridionalium dokumente o mletačko- južnoslavenskim odnosima pod nazivom: Listine o odnošajih izmedju južnoga Slavenstva i Mletačke Republike. Tom, iznimno važnom, serijom Akademija je preuzela onu zadaću koju je u hrvatskoj historiografiji od 1851. imao Kukuljevićev Arkiv, izdavanje izvorne građe iz mletačkih arhiva. I Matija Mesić je nakon toga, od 1868. dalje, svoje studije o hrvatskoj povijesti u razdoblju dinastije Jagelovića redovito objavljivao u Radu Akademije. ${ }^{7}$

U ostvarivanju prve od dviju temeljnih zadaća Akademije, objavljivanje arhivskih vrela, Ljubićeve Listine imaju iznimnu važnost. Prvih pet svezaka Listina, s građom od godine 960. do godine 1409., zaprema prvih pet knjiga serije Monumenta spectantia historiam Slavorum meridionalium, a do godine 1891. ukupno je $\mathrm{u}$ istoj seriji objavljeno deset svezaka Ljubićevih Listina, s građom do godine 1469. U šestoj knjizi te serije, godine 1876., Ljubić je počeo objavljivati drugu

\footnotetext{
Usp. T. RAUKAR, Pregled hrvatske poviesti Šime Ljubića i počeci moderne hrvatske historiografije, Zbornik o Šimi Ljubiću, Zagreb 2009, 21-39.

7 M. MESIĆ, Banovanje Petra Berislavića za kralja Ljudevita II., Rad 3, 1868, 1-64: ISTI, Hrvati nakon bana Berislavića do muhačke bitke, Rad 18, 1872, 77-163; Rad 22, 1873, 55-204. Usp. novo izdanje tih radova Matije Mesića u knjizi: M. MESIĆ, Hrvati na izmaku srednjega vijeka. Izabrane rasprave, Slavonski Brod 1996.
} 
važnu skupinu mletačkih vrela: Commissiones et relationes Venetae, dakle, upute mletačkim dužnosnicima na jadranskom dijelu mletačkih prekomorskih posjeda i njihove izvještaje Signoriji, pa je do godine 1880. Ljubić ukupno objavio tri sveska te zbirke, s izvornom građom od 1433. do 1571. godine. Mletačka komponenta hrvatske povijesti u kasnom srednjem vijeku i na početku novoga vijeka, prije svega u Dalmaciji, tek se nakon Ljubićevih izdanja mogla početi sustavno proučavati.

Napose valja istaknuti sedmu knjigu serije Monumenta spectantia historiam Slavorum meridionalium, jer je u njoj godine 1877. objavljeno kapitalno djelo hrvatske historiografije, Documenta historiae chroaticae periodum antiquam illustrantia Franje Račkoga, dakle, zbirka izvorâ o hrvatskoj povijesti u ranom srednjem vijeku koja je gotovo jedno stoljeće bila nezaobilaznom osnovicom u proučavanju toga razdoblja.

Spomenimo još nekoliko naslova iz te serije koju je Akademija pokrenula 1868. godine, odmah nakon prve knjige Rada 1867., da bismo ocrtali njezinu važnost i sadržajnu slojevitost. U desetoj knjizi (1879.) počinju se objavljivati odluke dubrovačkih vijeća pod naslovom: Monumenta Ragusina. Libri reformationum. U četrnaestoj knjizi (1883.) počinje podniz te serije pod nazivom Scriptores, prvi svezak, u kojemu su objavljene dubrovačke kronike: Annales Ragusini anonymi item Nicolai de Ragnina. U dvadeset i šestoj knjizi (1894.), odnosno trećem svesku podniza Scriptores objavljena je Historia Salonitana Tome Arhiđakona koju je priredio Franjo Rački. U tridesetpetoj knjizi (1914.) počinju se objavljivati Monumenta Habsburgica, dakle habsburški spomenici od godine 1526. dalje. Napokon, u četrdeset i drugoj knjizi (1917.) Vjekoslav Klaić je objavio Acta Keglevichiana, tj. najstarije isprave o velikaškom rodu Keglevića, među kojima se na početku zbirke nalaze isprave o hrvatskom plemenu Prkalj, iz kojega su Keglevići potekli, važne za određivanje društvenog položaja hrvatskoga nižega plemstva u prvoj polovici 14. stoljeća na području hrvatskoga kraljevstva južno od Velebita, između Zrmanje i Krke. ${ }^{8}$

Serija Monumenta spectantia historiam Slavorum meridionalium pokrenuta je ubrzo nakon utemeljenja Akademije, godine 1868., dok je desetak godina kasnije, 1877., pokrenuta još jedna važna serija: Monumenta historico-juridica Slavorum meridionalium, u kojoj su se objavljivali pravni spomenici hrvatske povijesti. Uz komunalne statute dalmatinskih gradova, Korčule, Splita, Budve, Skradina, grada i otoka Hvara, otoka Brača, otoka Lastova, Dubrovnika i Trogira, koji su odreda pisani na latinskom jeziku, $u$ toj su seriji u prvom razdoblju djelovanja Akademije objavljeni i pravni spomenici, pisani hrvatskim jezikom. U četvrtom svesku te

8 Usp. T. RAUKAR, Seljak i plemić hrvatskoga srednjovjekovlja, Zagreb 2002, 43-48. 
serije, pod naslovom Statuta lingua croatica conscripta (1890.), objavljeni su statuti, sastavljeni na hrvatskom jeziku, i to vinodolski, poljički, vrbanski, kastavski, veprinački i trsatski, dok su u petom svesku (1894.) objavljeni Hrvatski urbari. Urbaria lingua croatica conscripta. U šestom svesku (1898.) objavljeni su Hrvatski spomenici, tj. isprave na hrvatskom jeziku od 1100. do 1499. godine, u redakciji Đure Šurmina. ${ }^{9}$

Napokon, svemu tome valja dodati fundamentalnu, najvažniju zbirku izvorne građe za povijest hrvatskoga naroda u srednjem vijeku. To je Codex diplomaticus regni Croatiae, Dalmatiae et Slavoniae, odnosno Diplomatički zbornik kraljevine Hrvatske, Dalmacije i Slavonije, za kojega je građu za razdoblje od početka 12. do kraja 14. stoljeća sakupio Tadija Smičiklas. Taj se diplomatarij, ustvari, izravno nadovezuje na zbirku Documenta Franje Račkoga, objavljenu 1877. koja, kako je istaknuto, obuhvaća vrela za hrvatsku povijest u ranom srednjem vijeku, do početka 12. stoljeća. Zbog toga je Smičiklas u Predgovoru drugom svesku izrijekom istaknuo da smatra „Račkoga Documenta, koja sižu do godine 1100. kao prvi svezak ukupnoga Codex diplomaticus“, pa je svoj Diplomatički zbornik započeo s drugim sveskom, koji je objavljen godine 1904., a sadržava isprave od 1101. do 1200. godine..$^{10}$ Do godine 1914. Tadija Smičiklas je uredio i objelodanio još deset svezaka Diplomatičkoga zbornika, ukupno 11 svezaka, u nizu od 2. do 12. sveska, s građom do godine 1359. Nakon Smičiklasove smrti 13. svezak Diplomatičkog zbornik uredili su godine 1915. Marko Kostrenčić i Emilije Laszowski, s građom do godine 1366., dok je 14. svezak godine 1916. uredio Marko Kostrenčić, s građom do godine 1373. Objavljivanje 13 svezaka Diplomatičkog zbornika bilo je veoma znatan prinos Akademije, prije svega Tadije Smičiklasa i skupine njegovih suradnika, razvoju historiografije o hrvatskom srednjovjekovlju. Smičiklas i suradnici obavili su golem i zahtjevan posao prikupljanjem ispravâ u brojnim arhivima i zbirkama, koje su u iscrpnom Predgovoru drugom svesku poimence navedene, i na temelju tako odgovornih istraživanja pripremali pojedine sveske Diplomatičkog zbornika. Ako tome dodamo 43 knjige iz serije Monumenta spectantia historiam Slavorum meridionalium, koje su objavljene do godine 1918., smijemo zaključiti da je tako širokim zahvatom u objelodanjivanju povijesnih vrela o hrvatskom srednjovjekovlju Akademija nedvojbeno pokazala da je upravo ona ključna znanstvena institucija hrvatskoga naroda. Načelno je, dakako, Akademija imala južnoslavenski znanstveni program jer je njezin utemeljitelj, biskup Josip Juraj Strossmayer, smatrao da bi ona trebala biti znanstveno i kulturno sre-

\footnotetext{
9 Usp. Popis izdanja Jugoslavenske akademije znanosti i umjetnosti 1867-1985, urednici A. Stipčević i Lj. Filaković, Zagreb 1986, 286-287.

10 T. SMIČIKLAS, Diplomatički zbornik kraljevine Hrvatske, Dalmacije i Slavonije, svezak 2, Predgovor, Zagreb 1904, V-XXXI.
} 
dište oko kojega bi se okupljali svi južnoslavenski narodi i njihovi znanstvenici, pa je Akademija zbog toga i dobila jugoslavensko ime, ali povijesni razvoj drugih južnoslavenskih naroda nije bio u skladu s misaonim obzorima utemeljitelja Jugoslavenske akademije. Svi su južnoslavenski narodi, posve prirodno, drugačije nije ni moglo biti, razvijali vlastiti nacionalni identitet, pa su dosljedno tome osnivali i svoje nacionalne akademije znanosti. ${ }^{11}$ No i bez obzira na to, veoma je važno istaknuti da se Jugoslavenska akademija već od samoga utemeljenja, unatoč jugoslavenskom imenu i načelnom južnoslavenskom istraživačkom progra$\mathrm{mu}, \mathrm{u}$ većini svojih ostvarenja usmjeravala prema proučavanju povijesti hrvatskoga naroda. To jasno pokazuje već i znamenita, ovdje više puta spominjana, serija Akademije Monumenta spectantia historiam Slavorum meridionalium koja svojim imenom, istina, upućuje na zacrtani južnoslavenski znanstveni prostor, ali su unatoč tome u toj važnoj seriji pretežno bila objavljena vrela o hrvatskoj povijesti. No prikupljanje i izdavanje povijesnih vrela bilo je samo prvom, nedvojbeno najvažnijom, zadaćom Akademije, drugom je bilo objelodanjivanje ključnih istraživačkih studija, prije svega u Akademijinu Radu. Među povjesničarima koji su u prvom razdoblju djelovanja Akademije, do godine 1918., objavljivali temeljne istraživačke studije u Radu ističu se Franjo Rački i Vjekoslav Klaić.

Već u prvoj knjizi Rada iz 1867. godine Rački objavljuje osvrt na knjigu Božidara Petranovića Bogomili, crkva bosanska i krstjani (1867.), ali se Rački nije ograničio na ocjenu Petranovićeve knjige nego je već godine 1869. i 1870., u tri knjige Rada, objavio opsežnu studiju Bogomili i patareni..$^{12}$ Tako su Rački i Akademijin $\mathrm{Rad} \mathrm{u}$ hrvatskoj historiografiji otvorili novo istraživačko područje o "Crkvi bosanskoj" i bosanskim krstjanima koje je do danas ostalo jednim od njezinih prepoznatljivih obilježja i kojemu su nakon Račkoga važne prinose dali Jaroslav Šidak, Dragutin Kniewald, Dominik Mandić, Miroslav Brandt i Franjo Šanjek. ${ }^{13}$

No istraživanje o Crkvi bosanskoj i bosanskim krstjanima bilo je samo jednim dijelom široko zasnovanih istraživačkih nastojanja Franje Račkoga. Istodobno s objavljivanjem najstarijih hrvatskih vrela, do početka XII. stoljeća, u zbirci Documenta historiae chroaticae periodum antiquam illustrantia godine 1877., Rački

150 HAZU 1861-2011, 14-15.

12

13

F. RAČKI, Bogomili i patareni, Rad 7, 1869, 84-179; 8, 1869, 121-187; 10, 1870, 160-263.

J. ŠIDAK, Problem "bosanske crkve“ u našoj historiografiji od Petranovića do Glušca, Rad 259, 1937, 37182; ISTI, "Crkva bosanska“ i problem bogumilstva u Bosni, Zagreb 1940; D. KNIEWALD, Vjerodostojnost latinskih izvora o bosanskim krstjanima, Rad 270, 1949, 115-276; D. MANDIĆ, Bogomilska crkva bosanskih krstjana, Chicago 1962; J. ŠIDAK, Studije o "Crkvi bosanskoj“ i bogumilstvu, Zagreb 1975: F. ŠANJEK, Bosansko humski (hercegovački) krstjani $i$ katarsko-dualistički pokret u srednjem vijeku, Zagreb 1975; J. ŠIDAK, Heretička "Crkva bosanska“, Slovo 27, Zagreb 1977, 149-184; M. BRANDT, Izvori zla, Zagreb 1989; F. ŠANJEK, Bosansko-humski krstjani u povijesnim vrelima (13.-15. st.), Zagreb 2003. 
između 1876. i 1878. objavljuje nekoliko studija o hrvatskoj dvorskoj kancelariji i hrvatskim ranosrednjovjekovnim ispravama, kojima zapravo utemeljuje hrvatsku diplomatiku kao zasebnu pomoćnu povijesnu disciplinu, i stvara osnovicu za kritičko proučavanje najstarijih hrvatskih isprava. ${ }^{14}$

Tek nakon toga, kad je smatrao da je objavio i diplomatički ocijenio najstarije hrvatske isprave do početka XII. stoljeća, Rački pristupa proučavanju hrvatskoga društva u ranom srednjem vijeku, pa između 1881. i 1893. objavljuje svoje temeljne, za razvoj hrvatske medievalne historiografije istraživački najvažnije studije: Hrvatska prije XII. vieka glede na zemljišni opseg i narod, te, napose, Nutarnje stanje Hrvatske prije XII. stoljeća. ${ }^{15} \mathrm{U}$ studiji Hrvatska prije XII. vieka glede na zemljišni opseg i narod Rački razmatra, na temelju ranosrednjovjekovnih isprava i obavijesti pisaca, prostor Hrvatske u ranom srednjem vijeku i imena narodâ koji su taj prostor nastavali, te upozorava na dodir i prožimanje prvobitnoga, romanskoga stanovništva i novoga, slavensko-hrvatskoga etničkoga sloja. A u svojoj najvažnijoj studiji, koja je objavljena u šest knjiga Rada, Nutarnje stanje Hrvatske prije XII. stoljeća, Rački proučava, kako sâm ističe, „društvene odnošaje“ u Hrvatskoj. Redom analizira ustrojstvo društva, $u$ širokom rasponu od neslobodnih serva $i$ ancilla do plemstva, zatim državnu upravu i oblike vlasti te imovne i gospodarske odnose u ranosrednjovjekovnom hrvatskom kraljevstvu.

Nužno je istaknuti da su te dvije studije Franje Račkoga bile novo istraživačko područje u hrvatskoj historiografiji, pa su oblikovale sámu osnovicu za cjelokupno kasnije istraživanje o hrvatskom srednjovjekovnom društvu, prije svega u ranom srednjem vijeku, ili, drugim riječima, one su imale iznimnu važnost za razvoj historiografije o hrvatskom srednjovjekovlju.

Nakon Račkoga tu istraživačku osnovicu dopunjuje Vjekoslav Klaić dvjema svojim temeljnim studijama. U prvoj, Hrvatska plemena od XII. do XVI. stoljeća, Klaić je sabrao sve sačuvane podatke o postojanju i društvenoj ulozi hrvatskih plemena na području hrvatskoga kraljevstva, čime je znatno olakšao buduća istraživanja o njima. ${ }^{16} \mathrm{U}$ drugoj, Marturina, slavonska daća u srednjem vijeku, utemeljio je posve novu istraživačku disciplinu, proučavanje poreznog sustava $u$ kraljevini Slavoniji. ${ }^{17}$

14 F. RAČKI, Hrvatska dvorska kancelarija i njezine izprave za vladavine narodne dinastije, Rad 35, 1876, 1-49; ISTI, Stari priepisi hrvatskih izprava do XII. vieka prema maticam, Rad 36, 1876, 135-164; ISTI, Podmetnute, sumnjive i prerađene listine hrvatske do XII. vieka, Rad 45, 1878, 128-150. Nutarnje stanje Hrvatske prije XII. stoljeća, Rad 70, 1884, 153-190; 79, 1886, 135-184; 91, 1888, 125-180; 99, 1890, 73-128; 105, 1891, 202-238; 115, 1893, 37-67. 
Da bi u ovom sažetom prikazu predodžba o velikoj ulozi Akademije u razvoju hrvatske medievalne historiografije u prvom razdoblju njezina djelovanja, do kraja Prvoga svjetskog rata, bila barem donekle cjelovita, valja istaknuti da se povijesna vrela nisu objavljivala samo u seriji Monumenta spectantia historiam Slavorum meridionalium i u fundamentalnom izdanju Codex diplomaticus Tadije Smičiklasa nego i u Akademijinim Starinama. U toj ediciji, koja je pokrenuta već godine 1869., objavljivale su se kraće zbirke povijesnih vrela, pa je, primjerice, Šime Ljubić u Starinama objavio popise isprava zadarskoga samostana sv. Krševana i kartular Rogovskoga samostana, zvan Policorion..$^{18}$ I napokon, dodajmo da je između 1908. i 1918. objavljeno i prvih sedam svezaka Prinosa za hrvatski pravno-povjestni rječnik Vladimira Mažuranića, iznimno važno djelo za proučavanje i tumačenje srednjovjekovnih pravnih pojmova na hrvatskom području.

Navedeni podaci o djelovanju Akademije u njezinu prvom razdoblju, do kraja Prvoga svjetskoga rata, upućuju na dva važna zaključka.

Prvo, da je Akademija bila jedina znanstvena institucija u Hrvatskoj koja je u svojim, pomno priređenim, serijama mogla pokrenuti tako složeni izdavački program kojemu je ključna zadaća bila izdavanje izvora za hrvatsku srednjovjekovnu povijest, što je bio temeljni preduvjet za razvoj hrvatske medievalne historiografije, te usporedno s tim i objavljivanje istraživačkih studija.

Drugo, primjetno je da Akademija ni tada, a ni kasnije, nije objavljivala $u$ vlastitoj nakladi cjelovite preglede hrvatske srednjovjekovne povijesti, jer su svi takvi pregledi objavljeni mimo izdanja Akademije. No tome je važno dodati i činjenicu da su svi autori takvih pregleda u ovom prvom razdoblju djelovanja Akademije bili njezini pravi članovi, od Šime Ljubića preko Tadije Smičiklasa i Vjekoslava Klaića do Ferde Šišića. ${ }^{19}$ Zbog toga smijemo zaključiti da su njihovi pregledi hrvatske povijesti, mada su se objavljivali izvan Akademije i njezinih zacrtanih izdavačkih serija, ustvari nastajali u istraživačkom okrilju Akademije i u sklopu njezine uloge u razvoju hrvatske historiografije.

\section{Između dvaju svjetskih ratova}

U novim političkim prilikama nakon završetka Prvoga svjetskog rata, u sklopu kraljevine SHS, odnosno od godine 1929. Kraljevine Jugoslavije, eko-

18 S. LJUBIĆ, Dva popisa listina glasovitoga manastira sv. Krševana u Zadru, Starine, knjiga 19, 1887, 81-171; Libellus Policorion, qui Topicus vocatur, knjiga 23, 1890, 154-243.

19 ISTI, Pregled hrvatske poviesti, Rijeka 1867.; T. SMIČIKLAS, Poviest hrvatska, Dio prvi, Zagreb 1882; VJ. KLAIĆ, Povjest Hrvata od najstarijih vremena do svršetka XIX. stoljeća, Zagreb 1899-1911; F. ŠIŠIĆ, Pregled povijesti hrvatskoga naroda, Zagreb 1916; F. ŠIŠIĆ, Povijest Hrvata u vrijeme narodnih vladara, Zagreb 1925. 
nomski je položaj Akademije postao lošijim nego što je bio do 1918. godine, u Austro-Ugarskoj Monarhiji, pa je to utjecalo i na njezinu izdavačku djelatnost, a time i na ulogu u razvoju hrvatske historiografije. ${ }^{20}$ Premda se, dakle, izdavački i znanstveni prinos Akademije hrvatskoj medievalnoj historiografiji u razdoblju između dva svjetska rata ne može ni usporediti s iznimno plodnim djelovanjem Akademije $u$ prethodnom polustoljetnom razdoblju, od osnutka do kraja Prvoga svjetskog rata, ipak je nužno upozoriti da je Akademija i u posve skučenim financijskim okolnostima nastojala održavati kontinuitet izdavačke djelatnosti, mada u bitno smanjenom opsegu.

O izdavačkom zastoju dovoljno govori činjenica da je u čitavom razdoblju od 1918. do 1941. godine Akademija objavila samo jedan novi svezak Diplomatičkog zbornika, i to svezak 15., godine 1934., u redakciji Marka Kostrenčića, dok je Tadija Smičiklas, primjerice, u prethodnom razdoblju, u samo jednom desetljeću, između 1904. i 1914. godine, kako je već istaknuto, mogao objaviti čak 11 njegovih svezaka, što znači u prosjeku jedan svezak godišnje.

No upornost Akademije u održavanju nakladničkih serija najljepše je iskazivala njezina središnja edicija Rad. U podnizu Rada što su ga objavljivali prethodnici današnjega Razreda za društvene znanosti, Razredi historičko-filologički i filozofičko juridički, objavljeno je između 1919. i 1941. godine ukupno 26 knjiga Rada. Dodamo li tome razdoblje Drugoga svjetskog rata, kada je Hrvatska akademija znanosti i umjetnosti objavila još 5 knjiga Rada u istom podnizu Razredâ povijesno-jezikoslovnog i filozofsko-pravnoga, pokazuje se da je između 1918. i 1945. godine Akademija objavila ukupno 31 knjigu Rada toga podniza.

Zato su upravo u Radu Akademije objavljene neke od važnih istraživačkih studija u hrvatskoj historiografiji međuratnoga razdoblja. To su, primjerice, dvije studije Marka Kostrenčića, Vinodolski zakon i Slobode dalmatinskih gradova po tipu trogirskom, te veoma zanimljiv rad Tome Matića Hrvatski književnici mletačke Dalmacije $i$ život njihova doba. Taj se rad nije ograničavao na uže književno područje nego je, kako se to i u njegovu naslovu ističe, bio koncepcijski znatno širi, pa je ocrtavao i društveni život u mletačkom razdoblju povijesti Dalmacije, što je bio znak metodološkoga napredovanja tadašnje hrvatske historiografije. ${ }^{21}$

Napori Akademije oko izdavačkoga kontinuiteta očitovali su se i u nekim drugim serijama, izvan njezina Rada. U seriji Djela Jugoslavenske akademije znanosti i umjetnosti objavljen je godine 1925. bogato opremljeni Zbornik kralja Tomisla-

20150 HAZU 1861-2011, 17-19.

21 M. KOSTRENČIĆ, Vinodolski zakon, Rad 227, 1923, 110-230; ISTI, Slobode dalmatinskih gradova po tipu trogirskom, Rad 239, 1930, 56-150; T. MATIĆ, Hrvatski književnici mletačke Dalmacije i život njihova doba, Rad 231, 1925, 192-283; 233, 1927, 22-84. 
va, s podnaslovom $U$ spomen tisućgodišnjice hrvatskoga kraljevstva. Dapače, nakon naslovnice Jugoslavenska akademija znanosti i umjetnosti je u posebnoj posveti izrijekom istaknula da taj zbornik posvećuje "tisućugodišnjoj uspomeni prvoga hrvatskoga kralja Tomislava“. Na početku Zbornika nalazi se iscrpni uvodni tekst njegova urednika Gavre Manojlovića, tada predsjednika Akademije, Le millénaire de l'ancian royaume croate, a zatim slijede prilozi više istaknutih povjesničara, od Franje Račkoga i Ivana Kukuljevića do Vjekoslava Klaića i Ljudmila Hauptmanna, koji su pisali ili o kralju Tomislavu ili o hrvatskoj povijesti u ranom srednjem vijeku. ${ }^{22}$

Istom obljetničkom razdoblju pripada i već spomenuta kapitalna knjiga Ferde Šišića Povijest Hrvata u vrijeme narodnih vladara, također objavljena 1925. godine, ali ne u izdanju Akademije nego "Naklade školskih knjiga“ u Zagrebu, i to uz financijsku pomoć Svetozara Pribičevića, ministra u Ministarstvu prosvete Kraljevine SHS, kako to sâm Ferdo Šišić ističe u kraćoj uvodnoj napomeni. To pokazuje, s jedne strane, da Akademija tada nije bila financijski toliko jaka da bi mogla u svoj izdavački program uključiti, pokraj Zbornika kralja Tomislava, i Šišićevu Povijest, ali, s druge, upućuje i na činjenicu, koju je teško pouzdano objasniti, da je Ferdo Šišić, kao medievist najistaknutiji hrvatski povjesničar prve polovice 20. stoljeća, napose nakon smrti Vjekoslava Klaića (1928.), općenito malo objavljivao u izdanjima Akademije, premda je već od 1910. godine bio njezinim pravim članom. U Radu Akademije objavio je samo jednu studiju o habsburškohrvatskim odnosima nakon godine 1527., ${ }^{23}$ ali ipak valja reći da je tu prazninu barem donekle nadoknadio objavljivanjem iznimno važne zbirke izvora o hrvatsko-turskim odnosima u posljednjoj četvrtini 15. stoljeća u Starinama Akademije, pod naslovom Rukovet spomenika o hercegu Ivanišu Korvinu i o borbama Hrvata s Turcima (1473-1496). ${ }^{24}$

Među radovima koji su u izdanjima Akademije za Drugoga svjetskog rata bili smjernicom budućega razvoja hrvatske medievistike valja upozoriti na studiju Ljudmila Hauptmanna Podrijetlo hrvatskoga plemstva koja je godine 1942. objavljena u 273. knjizi Rada Hrvatske akademije znanosti i umjetnosti. ${ }^{25}$ Oslanjajući se prije svega na istraživačka postignuća Franje Račkoga, Vjekoslava Kla-

\footnotetext{
$\overline{22}$ O političkom i ideološkom okviru u kojemu se u Hrvatskoj 1925. godine obilježavala tisućugodišnjica hrvatskoga kraljevstva i u koju se po svemu uključuje i Akademijin Zbornik kralja Tomislava v.: H. MATKOVIĆ, Proslava tisućgodišnjice hrvatskoga kraljevstva 1925. godine i njezini odjeci u Hrvatskoj, u: Prvi hrvatski kralj Tomislav, Zbornik radova, Zagreb 1998, 271-280. 
ića i Ferde Šišića o ustrojstvu hrvatskoga društva u ranom srednjem vijeku, Hauptmann iznosi vlastito gledište o postanku hrvatskoga plemstva. Kada je iduće godine, 1943., Miho Barada objavio u Časopisu za hrvatsku poviest, dakle izvan izdavačkog programa Akademije, svoj rad Postanak hrvatskoga plemstva, bila je dograđena istraživačka osnovica koja će desetak godina kasnije postati predmetom intenzivnih istraživačkih nastojanja hrvatske historiografije o problemu postanka i razvoja hrvatskoga plemstva u srednjem vijeku. ${ }^{26}$

\section{Od obnove Akademije godine 1947. do danas}

Nakon Drugoga svjetskog rata hrvatska je historiografija doživjela temeljite promjene, institucionalne i metodološke, koje obilježavaju njezin razvoj do danas. Prvo, znatno je povećan broj ustanovâ kojima je zadaćom bilo povijesno istraživanje i, drugo, u tom dugom razdoblju metodološke su smjernice njihova istraživačkog rada iskazale nekoliko jasno određenih etapa. Pri tome je važno istaknuti da su se sve promjene $u$ organizaciji historiografskih istraživanja podjednako očitovale i u Akademiji i u povijesnim istraživanjima izvan njezina opsega.

U prva dva razdoblja koja smo dosad pratili Akademija je bila razvojnim središtem hrvatske historiografije, premda ne smijemo zanemariti činjenicu da su tada i neke druge institucije, prije svega arhivi i muzeji, poput Zemaljskog arkiva u Zagrebu i arheoloških muzeja u Zagrebu i Splitu, te njihovi časopisi, također bili uključeni u zajednički razvoj hrvatske medievalne historiografije. Ipak, tek se u ovom razdoblju, od Drugoga svjetskoga rata do danas, organizacija istraživačkog rada u hrvatskoj historiografiji znatno promijenila. Prije svega, utemeljeno je nekoliko instituta/zavoda izvan okvira Akademije kojima je zadaćom bilo istraživanje hrvatske povijesti, primjerice Hrvatski institut za povijest u Zagrebu, a istodobno je i u sastavu Akademije osnovano više takvih znanstvenoistraživačkih jedinica.

Već godine 1948. utemeljen je Historijski institut Jugoslavenske akademije u Zagrebu, a iste godine u sastav Akademije ulazi Jadranski institut u Sušaku, koji je 1945. godine utemeljilo Predsjedništvo NR Hrvatske. Historijski institut u Dubrovniku utemeljen je 1949. godine, a 1954. godine Institut Jugoslavenske akademije u Zadru. Mreža znanstvenoistraživačkih jedinica Akademije postupno se dopunjavala, pa je danas gotovo ravnomjerno proširena na čitavom prostoru Republike Hrvatske. ${ }^{27}$ To je nužno uvjetovalo primjetne promjene u organizaciji istraživačkog rada na području medievalne historiografije.

26 Usp. RAUKAR, Seljak i plemić hrvatskoga srednjovjekovlja i tamo navedena literatura.
27 150 HAZU 1861 - 2011, karta na str. 254 . 
U čitavom dotadašnjem djelovanju Akademije na tom su području istraživačkim uporištem bili Razredi historičko-filologički i filozofičko-juridički. U njihovu su se okviru određivala područja i ciljevi istraživačkoga rada na području historiografije, a znanstveni je ishod prije svega ovisio o djelovanju njihovih pravih članova. Istina, oni su nužno morali surađivati sa stručnjacima izvan Akademije, kako je to, primjerice, postupio Tadija Smičiklas prilikom prikupljanja izvorne građe u brojnim arhivskim ustanovama za Diplomatički zbornik, ali je ipak težište istraživačkog rada bilo na članovima Razreda.

Osnivanjem institutâ, kasnije zavodâ, istraživačka se osnovica Akademije na području historiografije znatno proširila i ojačala. Odjel za filozofiju i društvene nauke (od 1947.) i njegovi nasljednici do današnjega Razreda za društvene znanosti (od 1972.) i dalje su bili organizacijskim središtem historiografskoga rada unutar Akademije, ali su u novim okolnostima tek pokrenuti instituti preuzimali i vlastite istraživačke zadaće. Istodobno se promijenilo i ustrojstvo nakladničke djelatnosti. Pokraj ranijih izdavačkih serija Akademije koje su bile važne za razvoj hrvatske historiografije, pa su sve do danas ostale osnovicom nakladničke djelatnosti Akademije, primjerice Rad podniza Odjela za filozofiju i društvene nauke, od 1972. Razreda za društvene znanosti, zatim Starine ili serija Monumenta spectantia historiam Slavorum meridionalium, pojavila su se nova izdanja koja su objavljivali novoutemeljeni instituti, odnosno zavodi, prije svega njihovi časopisi. Evo nekoliko primjera.

Historijski institut JAZU u Dubrovniku prvi je godine 1952. pokrenuo svoj časopis, Anali Historijskog instituta JAZU u Dubrovniku, danas Anali Zavoda za povijesne znanosti HAZU u Dubrovniku. Do godine 2017. objavljeno je ukupno 56 svezaka Anala. Od 1997. godine Zavod objavljuje i časopis na engleskom jeziku, Dubrovnik Annals, a do 2017. objavljen je 21 svezak tog časopisa. Historijski institut u Zagrebu 1954. godine počeo je izdavati Zbornik Historijskog instituta Jugoslavenske akademije u Zagrebu, danas Zbornik Odsjeka za povijesne znanosti Zavoda za povijesne $i$ društvene znanosti HAZU, pa je do 2017. godine u toj seriji objavljeno ukupno 35 svezaka časopisa. Iste je godine (1954.) i Institut JAZU u Zadru pokrenuo svoj časopis, Radovi Instituta JAZU u Zadru, danas Radovi Zavoda za povijesne znanosti HAZU u Zadru; do 2017. objavljena su ukupno 52 sveska tog časopisa. ${ }^{28}$ I napokon, Jadranski institut u Rijeci počeo je 1963. godine objavljivati časopis Problemi sjevernog Jadrana, pa je Zavod za povijesne i društvene znanosti u Rijeci s Područnom jedinicom u Puli do godine 2017. objavio 15 svezaka tog časopisa.

Drugom važnom značajkom hrvatske historiografije u ovom razdoblju, kako je istaknuto, bile su promjene u njezinim metodološkim osnovama. U prvom

$\overline{28}$ Iscrpnije o znanstveno-istraživačkim jedinicama Akademije v. 150 HAZU 1861 - 2011, 63-72, 242-248. 
poratnom razdoblju hrvatska je historiografija bila zahvaćena novim metodološkim smjernicama koje su upućivale na veću istraživačku pozornost prema društvenom, napose gospodarskom razvoju. Te su se smjernice, doduše, teorijski temeljile na ideološkim gledištima dogmatskog marksizma, ali je ipak nedvojbeno da su one jednim dijelom i poticajno djelovale na praktična istraživanja hrvatske historiografije, $\mathrm{u}$ tom sklopu i na djelovanje Akademije, kako pojačanim zanimanjem za istraživanja o hrvatskom srednjovjekovnom društvu, tako i utemeljenjem nove izdavačke serije, Građa za gospodarsku povijest Hrvatske.

Već godine 1951. Mijo Mirković, istaknuti član Odjela za filozofiju i društvene nauke, objavljuje, doduše, izvan okvira Akademijinih izdanja, prilog O ekonomskim odnosima u Trogiru u XIII. stoljeću koji lijepo ocrtava nove metodološke tendencije $\mathrm{u}$ hrvatskoj medievalnoj historiografiji u prvim poratnim godinama. ${ }^{29}$ Na pojačano zanimanje za istraživanja o srednjovjekovnom društvu upućuje i knjiga Mihe Barade Hrvatski vlasteoski feudalizam po Vinodolskom zakonu, objavljena 1952. u izdanjima Akademije. Premda je tu knjigu i njezine zaključke ubrzo žestoko osporio Marko Kostrenčić, ipak je ona bila koristan prinos razmišljanju o oblicima društvenoga ustrojstva u srednjovjekovnoj Hrvatskoj koji je, u najmanju ruku, otvarao putove novim istraživanjima. ${ }^{30}$

Još više to vrijedi za drugu knjigu Mihe Barade Starohrvatska seoska zajednica iz 1957. godine, također u izdanjima Akademije. Mada se i ta knjiga nužno temeljila na nekim hipotetičkim rješenjima autora, pa je i ona prije svega bila korisna kao osnovica budućih istraživanja, ipak je njezina sudbina bila bolja od one koju je doživjela prethodna Baradina knjiga o Vinodolskom zakonu, i to zbog odmjerenog stava recenzenta, Mije Mirkovića, u Odjelu za filozofiju i društvene nauke, koji je, unatoč neslaganju u pojedinostima, predložio objavljivanje rukopisa i upozorio na njegovu važnost za razvoj historiografije. ${ }^{31}$

Unatoč tome, najvažnijim plodom novih metodoloških gledišta bilo je osnivanje nove Akademijine izdavačke serije Građa za gospodarsku povijest Hrvatske. Ta je serija pokrenuta 1951. godine, a do godine 2012. objavljene su ukupno 22 knjige u toj seriji. S motrišta hrvatske medievalne historiografije ta serija upućuje na dvije važne pojave.

Prvo, objavljene se knjige iz te serije uglavnom odnose na hrvatsku novovjekovnu povijest, prije svega na 19. i 20. stoljeće, dok se na srednjovjekovno raz-

M. MIRKOVIĆ, O ekonomskim odnosima u Trogiru u XIII. stoljeću, Historijski zbornik IV, 1951, 21-54.

30 M. KOSTRENČIĆ, O radnji Prof. dr. Mihe Barada Hrvatski vlasteoski feudalizam, Predavanja održana u Jugoslavenskoj akademiji, svezak 9, Zagreb 1953.

31 Arhivska zbirka Razreda za društvene znanosti HAZU, godina 1955., referat Mije Mirkovića, 10.XII.1955.
} 
doblje dijelom ili u cjelini odnose samo četiri. Na srednjovjekovno se razdoblje prije svega odnose dvije monografije Dragana Rollera iz ekonomske povijesti srednjovjekovnog Dubrovnika, o razvoju dubrovačkih obrta u 15. i 16. stoljeću i o agrarnim odnosima na području Dubrovačke Republike od 13. do 15. stoljeća. Na srednjovjekovno razdoblje pretežno se odnosi kapitalna knjiga Josipa Adamčeka o agrarnim odnosima u Hrvatskoj potkraj srednjega i u novom vijeku i monografija Zlatka Herkova o povijesti zagrebačke trgovine. ${ }^{32}$ To pokazuje da je istraživanje gospodarskog razvoja u srednjovjekovnim društvima bilo u sjeni proučavanja novovjekovne i moderne gospodarske povijesti.

Drugo, činjenica da je posljednja knjiga iz te serije, knjiga Vladimira Stipetića Dva stoljeća razvoja hrvatskoga gospodarstva (1820-2005), objavljena 2012. godine, dakle čak 25 godina nakon knjige Zlatka Herkova, svjedoči o postupnom zamiranju važnog istraživačkog područja u hrvatskoj historiografiji, ekonomske povijesti. ${ }^{33}$ Primjetno slabljenje zanimanja za istraživanja o gospodarskoj povijesti do danas obilježavaju i hrvatsku medievalnu historiografiju, kako unutar Akademije, tako i izvan nje.

No usporedno sa zamiranjem istraživačkog interesa za ekonomsku povijest srednjega vijeka, historiografija je ulazila u novo razvojno razdoblje, obilježeno sve intenzivnijim proučavanjem cjelovitosti društvenoga razvoja. Otvarala su se nova istraživačka područja o važnim pojavama u srednjovjekovnim društvima kakvima, primjerice, bijahu marginalizacija i isključivanje, skrb društvenih zajednica za siromašne i ovisne ili misaona osjećajnost srednjovjekovnih ljudi koju ocrtavaju srednjovjekovne oporuke i njihovi legati i sl. ${ }^{34}$ Pri tome valja istaknuti da su u metodološkoj modernizaciji hrvatske historiografije primjerenu ulogu imala i izdanja Akademije, napose časopisi njezinih zavoda i, dakako, njihovi djelatnici.

Upravo su časopisi institutâ/zavodâ bili osnovicom Akademijine djelatnosti u proučavanju srednjovjekovne hrvatske povijesti. U tim je časopisima objavljeno mnoštvo znanstvenih priloga o hrvatskom srednjovjekovlju koji su izravno djelovali na razvoj hrvatske historiografije, pa je i cjeloviti prinos Akademije

32 D. ROLLER, Dubrovački zanati u XV. i XVI. stoljeću, Zagreb 1951.; D. ROLLER, Agrarno-proizvodni odnosi na području Dubrovačke republike od XIII. do XV. stoljeća, Zagreb 1955.; J. ADAMČEK, Agrarni odnosi u Hrvatskoj od sredine XV do kraja XVII stoljeća, Zagreb 1980, Z. HERKOV, Povijest zagrebačke trgovine, Zagreb 1987.

33 Usp. T. RAUKAR, Četiri desetljeća historiografije o hrvatskom srednjovjekovlju (1945-1985), Historijski zbornik XLI, 1988, 70.

34 D. KARBIĆ, Marginalne grupe u hrvatskim srednjovjekovnim društvima od druge polovine XIII. do početka XVI. stoljeća, Historijski zbornik XLIV, 1991, 43-76; T. RAUKAR, Moćni i marginalizirani u hrvatskom srednjovjekovlju, Rad 500, 2008, 201-237; Z. LADIĆ, Last will: passport to heaven, Zagreb 2012. 
istraživanju srednjovjekovnog razdoblja hrvatske povijesti u ovom razdoblju bio višestruko povećan.

Na pojedinačne priloge $u$ časopisima, dakako, nemoguće je upozoravati $u$ ovom kratkom prilogu, ali bih spomenuo barem neke studije koje su iz temelja promijenile naša shvaćanja o pojedinim pitanjima hrvatske povijesti u srednjem vijeku. Tako je, naprimjer, rad Vesne Jakić Cestarić, Etnički odnosi u srednjovjekovnom Zadru prema analizi osobnih imena, na posve nov način, na razini etnodruštvenih romansko- hrvatskih dodira, osvijetlio odnose između hrvatskoga zaleđa i dalmatinskih gradova u ranom srednjem vijeku, dok je prilog Luje Margetića, Konstantin Porfirogenet i vrijeme dolaska Hrvata, široko odjeknuo u historiografiji i ponovno pokrenuo istraživanja o doseobi Hrvata. ${ }^{35}$ Korisno je nadalje istaknuti i to da su se u časopisima Akademijinih zavoda ponekad objavljivale i važne zbirke vrela za hrvatsku povijest u srednjem vijeku. Tako su, naprimjer, u Zborniku Zavoda za povijesne znanosti JAZU u Zagrebu objavljeni zapisnici Velikog vijeća splitske komune iz sredine 14. stoljeća. ${ }^{36}$ No uloga Akademijinih zavoda u istraživanju hrvatske srednjovjekovne povijesti nije se ograničavala na objavljivanje zbirki vrela i znanstvenih priloga u svojim časopisima. Zavodi su se uključivali $\mathrm{u}$ istraživanja i objelodanjivanja izvorne građe i u redovitim izdavačkim serijama Akademije.

Na prvome mjestu valja spomenuti nastavak rada na Diplomatičkom zborni$k u$ Tadije Smičiklasa. U Historijskom institutu u Zagrebu Jakov Stipišić i Miljen Šamšalović priredili su prvi svezak Diplomatičkog zbornika, s građom od 743. do 1100. godine, koji je zamijenio Documenta historiae chroaticae periodum antiquam illustrantia Franje Račkoga iz godine 1877. ${ }^{37}$ Tek je sada Diplomatički zbornik uistinu započinjao od prvoga sveska, ali je istodobno u istom Akademijinu zavodu nastavljen i rad na njegovim preostalim svescima, s izvornom građom do kraja 14. stoljeća koju je bio prikupio Tadija Smičiklas. Između 1976. i 1990. godine objavljena su tri sveska Diplomatičkog zbornika. Godine 1976., objavljen je 16. svezak s građom od 1379. do 1385. godine, što ga je uredio Marko Kostrenčić, a dopunili Jakov Stipišić i Miljen Šamšalović. Sedamnaesti svezak, s građom od 1386. do 1394., objavljen je godine 1981., urednikom mu je bio Stjepan Gunjača, a dopunio ga je Jakov Stipišić. I napokon, godine 1990. objavljen je 18. svezak, s

\footnotetext{
35 V. JAKIĆ-CESTARIĆ, Etnički odnosi u srednjovjekovnom Zadru prema analizi osobnih imena, Radovi Instituta JAZU u Zadru, 19, 1972, 99-166; L. MARGETIĆ, Konstantin Porfirogenet i vrijeme dolaska Hrvata, Zbornik Historijskog zavoda JAZU , 8, Zagreb 1977, 5-88.

36 J. STIPIŠIĆ - M. ŠAMŠALOVIĆ, Zapisnici Velikog vijeća grada Splita. Libri Maioris consilii civitatis Spalati. 1352-1354, 1357-1359, Zbornik Zavoda za povijesne znanosti JAZU, 12, 1987, 63-266.

37 Diplomatički zbornik Kraljevine Hrvatske, Dalmacije i Slavonije, sv. I, sakupili i priredili J. Stipišić M. Šamšalović, uredio M. Kostrenčić, Zagreb 1967.
} 
građom od 1395. do 1399. godine, a uredio ga je Duje Rendić-Miočević, uz dopune Miljena Šamšalovića sa suradnicima (V. Gamulin, D. Karbić, Z. Ladić, M. Matijević-Sokol, R. Modrić i J. Stipišić).

No u gotovo stogodišnjem vremenskom rasponu što je dijelio početke rada Tadije Smičiklasa na prikupljanju građe za Diplomatički zbornik potkraj 19. stoljeća i njegova konačnog dovršetka 1990. godine pronađen je znatan broj do tada nepoznatih isprava koje nisu mogle biti u nj uključene, pa je bilo nužno pristupiti izradi i objavljivanju dodataka Diplomatičkom zborniku, s izvornom građom do godine 1399. Do sada su objavljena dva sveska edicije Diplomatički zbornik kraljevine Hrvatske, Dalmacije i Slavonije. Dodaci, prvi 1998. i drugi 2002. godine.

Prvi svezak, s izvornom građom od 1020. do 1270. godine objavljen je u suradnji između Akademije i Hrvatskog državnog arhiva u Zagrebu, s urednicima Hodimirom Sirotkovićem i Josipom Kolanovićem, a priredili su ga Josip Barbarić i Jasna Marković uz pomoć skupine suradnika (V. Gamulin, J. Lučić, M. Matijević- Sokol, I. Mustać i J. Neralić). Drugi svezak, s građom od 1271. do 1309. godine i urednikom Hodimirom Sirotkovićem, objavila je sama Akademija i njezin Odsjek za povijesne znanosti u Zagrebu, a priredili su ga Josip Barbarić i Jasna Marković s istim suradnicima koji su sudjelovali i pri izradi prvoga sveska.

Nadalje, nakon duge, tridesetogodišnje stanke ponovno je pokrenuta serija Monumenta spectantia historiam Slavorum meridionalium. U tri knjige te serije Miho Barada objavio je trogirske notarske spise iz druge polovice 13. stoljeća, što je samo po sebi bilo iznimno značajno, ali još važnije zbog činjenice što je veći dio tih najstarijih notarskih spisa na istočnoj obali Jadrana uništen $u$ požaru gradske vijećnice u Trogiru u Drugom svjetskom ratu. ${ }^{38}$ Grga Novak je, pak, u pet svezaka objavio Mletačka uputstva $i$ izvještaje od godine 1572. do 1680. godine, nastavljajući se na ediciju Commissiones et relationes venetae, koju je između 1876. i 1880. bio pokrenuo Šime Ljubić. ${ }^{39}$

Nakon još jedne stanke od dvadeset i pet godina obnovljena su izdanja $\mathrm{u}$ seriji Monumenta spectantia historiam Slavorum meridionalium. U Odsjeku za povijesne znanosti u Zagrebu priređen je prvi svezak nove edicije Splitski spomenici, u kojemu su objavljeni najstariji sačuvani splitski notarski spisi iz 40-ih

\footnotetext{
38 Trogirski spomenici. Dio I. Zapisnici pisarne općine trogirske. Sv. I., 1263-1273, Monumenta spectantia historiam Slavorum meridionalium 44, 1948, prepisao i uredio Miho Barada; Sv. II., 1274-1294, 45, 1950, prepisao i uredio Miho Barada; Dio II. Zapisnici sudbenog dvora općine trogirske, Sv. I, 1266-1299, 46, 1951, prepisao i uredio Miho Barada.

Mletačka uputstva i izvještaji, MSHSM 47-51, 1964-1977, sabrao i obradio Grga Novak.
} 
godina XIV. stoljeća. ${ }^{40} \mathrm{U}$ idućem svesku iste serije objavljeno je kapitalno, izvrsno priređeno izdanje Obsidio Iadrensis. Opsada Zadra. ${ }^{41}$

Instituti, odnosno zavodi, dali su znatan prinos ulozi Akademije u razvoju hrvatske historiografije i vlastitim izdanjima, kako objavljivanjem znanstvenih monografija, tako i priručnicima i rječnicima koji su priređeni u njihovu okrilju. U Historijskom institutu u Zagrebu Zlatko Herkov izradio je veoma vrijedan priručnik Građa za financijsko-pravni rječnik feudalne epohe Hrvatske, a zajedno s Markom Kostrenčićem i Veljkom Gortanom također iznimno vrijedan Rječnik srednjovjekovnog latiniteta Jugoslavije. ${ }^{22}$ Nadalje, Jakov Stipišić objavio je, doduše izvan izdanja Akademije, izvrsni priručnik Pomoćne povijesne znanosti u teoriji i praksi, a Ante Gulin više knjiga o razvoju srednjovjekovnih kaptola na hrvatskom području. ${ }^{43}$

Zavod za povijesne znanosti u Dubrovniku, pak, obogatio je Akademiju i hrvatsku historiografiju zbirkom monografija o povijesti Dubrovnika i Dubrovačke Republike. Među njima neka budu spomenuti barem neki od najnovijih naslova: Zlata Blažina Tomić, Kacamorti i kuga. Utemeljenje i razvoj zdravstvene službe u Dubrovniku (2007), Nenad Vekarić, Nevidljive pukotine. Dubrovački vlasteoski klanovi (2009.), i, napose, Nenad Vekarić, Vlastela grada Dubrovnika. Korijeni, struktura i razvoj dubrovačkog plemstva. Do godine 2017. od ove posljednje edicije ukupno je objavljeno 8 svezaka, ali, nažalost, autor nije uspio objelodaniti cjelovito djelo koje je prema njegovoj zamisli trebalo imati 11 svezaka. Ipak, valja se nadati da je Nenad Vekarić priredio tekst preostala tri sveska jedinstvenog rada o dubrovačkom plemstvu i da će naporom dubrovačkog Zavoda njegovi preostali dijelovi biti u cjelini objelodanjeni.

Ulozi Akademijinih zavoda u razvoju hrvatske medievalne historiografije valja dodati $i$ to da su se $u$ to istraživačko područje uključivali i interdisciplinarni zavodi za znanstveni rad, koji se nisu nalazili u nadležnosti Razreda za društvene znanosti. Primjerom je Zavod za znanstveni rad u Varaždinu koji je s dva bogato opremljena zbornika obilježio početke grada, najprije 800 . obljetnicu prvog spomena Varaždina u sačuvanim vrelima godine 1181., a zatim i 800. obljetnicu privilegija kralja Andrije II. iz 1209. kojim je Varaždin proglašen

\footnotetext{
Splitski spomenici, Dio prvi, svezak 1. Spisi splitskog bilježnika Ivana pok. Çove iz Ankone, od 1341. do 1344. godine, MSHSM 53, 2002., prepisao Jakov Stipišić.

Obsidio Iadrensis. Opsada Zadra, MSHSM 54, 2007, priredili V. Gortan, B. Glavičić, V. Vratović, D. Karbić, M. Kurelac, Z. Ladić.

Z. HERKOV, Građa za financijsko-pravni rječnik feudalne epohe Hrvatske, svezak I i II, 1956; M. Kostrenčić, V. Gortan, Z. Herkov, Lexicon latinitatis medii aevi Iugoslaviae, svezak I., 1973; svezak II, 1978. 
slobodnim kraljevskim gradom, pa je dio znanstvenih priloga u njima bio posvećen i srednjovjekovnim temama o povijesti Varaždina. ${ }^{44}$

Dakako, Akademija je objavljivala važna izdanja o hrvatskoj srednjovjekovnoj povijesti i izvan okvira svojih znanstvenoistraživačkih jedinica. Ubrzo nakon obnove djelatnosti Akademija je 1952. objavila kartular samostana sv. Petra u Selu, nešto kasnije, 1959., još jedan kartular, samostana sv. Marije u Zadru. ${ }^{45}$ Suvišno je reći koliko su ta dva kartulara važna za poznavanje hrvatske povijesti u ranom srednjem vijeku, tim prije što su oba izdanja bila uzorno priređena. Povijesnu, paleografsku i diplomatičku analizu oba kartulara izvršio je Viktor Novak, dok je Petar Skok u Supetarskom kartularu dodao lingvističku analizu njegova teksta. Kako izdanja obaju kartulara ne sadržavaju samo transkripciju nego i faksimile njihova teksta, to su oni pouzdana osnovica za svako njihovo daljnje proučavanje.

I napokon, Akademija je razvoj historiografije o hrvatskom srednjovjekovlju podupirala i održavanjem znanstvenih skupova u povodu velikih obljetnica iz hrvatske povijesti. Takvima su bili, primjerice, skup o 1000. obljetnici nadgrobnog natpisa kraljice Jelene (1976.), zatim o 800. obljetnici Povaljske listine i Povaljskog praga (1984.), o 700. obljetnici Vinodolskog zakona (1988.), o 1100. obljetnici natpisa kneza Branimira iz Muća Donjeg (1988) ili o 900. obljetnici smrti kralja Zvonimira (1989.). Nažalost, takvi znanstveni skupovi nisu uvijek okončani pojavom zbornikâ s prilozima sudionika. Zbornici su objavljeni nakon skupa o Povaljskoj listini i Povaljskom pragu te nakon skupa o 900. obljetnici smrti kralja Zvonimira. ${ }^{46}$ Skupovi o Vinodolskom zakonu i o natpisu kneza Branimira iz 888., održani 1988., nažalost, ostali su bez zbornika radova. Sa znanstvenog skupa o nadgrobnom natpisu kraljice Jelene iz 976. godine objavljen je prilog Duje Rendića-Miočevića. ${ }^{47}$

44 Varaždinski zbornik, Varaždin 1983.; 800 godina slobodnog kraljevskog grada Varaždina 1209.-2009, Zagreb - Varaždin 2009.

V. NOVAK - P. SKOK, Iura sancti Petri de Gomai. Supetarski kartular, Zagreb 1952; V. NOVAK, Zadarski kartular samostana svete Marije, Zagreb 1959.

46 Obljetnica Povaljske listine i Praga, 1184.-1984, Brački zbornik XV, Supetar 1987; Zvonimir kralj hrvatski, Zagreb 1997.

47 D. RENDIĆ-MIOČEVIĆ, Neke epigrafsko-onomastičke značajke epitafa kraljice Jelene (U povodu tisuće obljetnice natpisa, Arheološki radovi i rasprave VIII-IX, 1982, 219-231; pretisak u: D. RENDIĆ-MIOČEVIĆ, Dalmatia christiana. Opera omnia, uredio N. Cambi, Zagreb - Split 2011., 241-257. 
Rad Hrvat. akad. znan. i umjet. Razred za druš. znan. 53=535(2018) : 37-58

\section{Zaključni pogled}

U prethodnom izlaganju o ulozi Akademije u razvoju historiografije o hrvatskom srednjovjekovlju osnovicom je bila historiografija u užem smislu, dakle ona koju prije svega obilježava istraživanje o političkom, društvenom ili gospodarskom razvoju, ali sam veoma zadovoljan što ovdje, u zaključku, mogu reći da gornje odrednice nipošto ne iscrpljuju složeni pojam hrvatskoga srednjovjekovlja. Dapače, tom se pojmu može pristupiti samo interdisciplinarnim postupcima, kojima u naša istraživanja uključujemo iznimno plodne rezultate drugih humanističkih znanosti, primjerice, arheologije, jezikoslovlja, znanosti o književnosti, o likovnom stvaralaštvu i umjetnosti kodeksa ili o glazbenoj umjetnosti jer bez njih uopće ne bismo mogli ocrtati svu razvojnu složenost i bogatu stvaralačku baštinu hrvatske srednjovjekovne povijesti. Na taj način i uloga Akademije i njezinih razredâ u razvoju historiografije o hrvatskom srednjovjekovlju biva istaknutijom i opsežnijom nego što bi bila kada bismo zaključivali samo prema rezultatima historiografije u užem smislu, premda već i oni, kako je ovdje bilo izloženo, upućuju na iznimno važnu ulogu Akademije.

U ovoj je prilici, dakako, nemoguće navesti sve autore i njihova djela na koja se interdisciplinarni postupak oslanja. Neka mi stoga bude dopušteno spomenuti samo nekoliko ilustrativnih primjera. Kako, primjerice, razmatrati važnost antičke osnovice na istočnom Jadranu u stvaranju hrvatskoga srednjovjekovnoga društva bez knjige Mate Suića Antički grad na istočnom Jadranu (1976.) ili pak, kako razumjeti taj razvoj bez izričaja Tropismena i trojezična kultura hrvatskoga srednjovjekovlja (1985-1986.) kako glasi naslov, za povjesničara ključne, knjige Eduarda Hercigonje, zatim, kako to činiti bez knjigâ Radoslava Katičića Uz početke hrvatskih početaka (1993.) ili Litterarum studia (1998.)?

Nadalje, kako razumjeti spomeničku baštinu hrvatskoga srednjovjekovnoga prostora bez ključnih ostvarenja povjesničara umjetnosti u proteklom stoljeću, primjerice, od knjige Umjetnost u Dalmaciji. XV. i XVI. vijek (1933.) Ljube Karamana preko Zadarskih sredovječnih majstora (1959.) Cvita Fiskovića, knjige s posve novim znanstvenim obzorima o zadarskim majstorima, ili Slikara Blaža Jurjeva (1965.) Krune Prijatelja do Vincenta iz Kastva (1992.) Branka Fučića?

Spoznaje o stvaralaštvu u hrvatskom srednjovjekovnom društvu koje se nalaze okupljene u tim djelima, kao i u brojnim drugima koja ovdje nisu mogla biti izrijekom spomenuta, a koja su iznimno važna za historiografiju o hrvatskom srednjovjekovlju, objavljena su, doduše, izvan izdavačkih serija Akademije, ali uza sve to valja istaknuti da su svi autori gore spomenutih djela bili njezini redoviti članovi, što znači da su i ta djela na svoj način odnjegovana unutar Akademije. Ta činjenica sama po sebi svjedoči o njezinoj još istaknutijoj ulozi u proučavanju hrvatske povijesti u proteklih stoljeće i po njezina postojanja. 
I napokon, u okrilju je Akademije u 90-im godinama prošloga stoljeća, na poticaj i uz iznimnu brižnost Ivana Supičića, nastala edicija Hrvatska i Euro$p a$, neusporediva s bilo čim drugim, kako po važnosti njezinih poruka svima nama, ali ipak prije svega drugima, znanstvenoj javnosti izvan nas, tako i po likovnoj ljepoti njezinih svjedočanstava o hrvatskoj stvaralačkoj baštini i narodnom identitetu. Prvi svezak edicije Hrvatska i Europa ima naslov Rano doba hrvatske kulture, drugi Srednji vijek i renesansa, oba pak nose podnaslov Kultura, znanost i umjetnost. Prvi je svezak objavljen 1997., drugi 2000. godine. Ti svesci govore o kulturi i stvaralaštvu na hrvatskom prostoru u dugom rasponu od antičke osnovice preko srednjega vijeka do renesanse.

Smjelo bi se, dakle, reći da ta edicija svojim sadržajnim bogatstvom okrunjuje stoljeće i po dugo vrijeme postojanja i djelovanja Akademije i da ona upravo simbolički obilježava njezin dosadašnji razvojni luk kojemu je na početku bio zanos utemeljitelja, biskupa Josipa Jurja Strossmayera, ali i pregalaštvo Franje Račkoga, Šime Ljubića ili Tadije Smičiklasa, a na njegovu kraju jedinstvena edicija Hrvatska $i$ Europa.

Da zaključim. Plodna djelatnost Hrvatske akademije znanosti i umjetnosti i njezinih Razreda na području historiografije i humanističkih znanosti općenito bila je od početaka do danas važna, nezaobilazna sastavnica u razvoju historiografije o hrvatskom srednjovjekovlju. A tako istaknutu ulogu Akademije $\mathrm{u}$ istraživanju povijesti hrvatskoga naroda i njegova stvaralaštva dužni smo i u budućnosti još više razvijati i njegovati. 


\section{Summary}

\section{The Croatian Academy of Sciences and Arts and the Historiography of the} Middle Ages in Croatia

The Croatian Academy of Sciences and Arts has played a major and important role in the development of historiography studying the mediaeval period in Croatian history. The most comprehensive sources of information regarding this topic are festive surveys or memorial editions on the operation of the Academy; in particular the last one published so far - the edition of 2011, marking the 150th anniversary of the foundation of the Academy. Nevertheless, a systematic evaluation of the abovementioned role has still not been published. In the few complete surveys of the development of Croatian historiography, the Academy is usually mentioned only casually, concentrating mainly on its publishing activity. Hence, these texts tackle only the publishing role of the Academy appropriately, whereas the importance of the Academy in the development of Croatian historiography has been evaluated in exceptional cases only.

Keywords: historiography of the Middle Ages; Croatian Academy of Sciences and Arts; Croatian history; bibliography. 